\title{
ASSOCIATION BETWEEN MATERNAL EDUCATION, FAMILY INCOME, AND INFANT DEVELOPMENT, IN COMMUNITY HEALTH CENTER PENELEH, SURABAYA
}

\author{
Rukmini1,2), Bhisma Murti3), Nunuk Suryani4) \\ 1) Adi Husada Nursing Academy, Surabaya \\ 2) Masters Program in Family Medicine, \\ Sebelas Maret University, Surakarta \\ 3) Masters Program in Public Health, Sebelas Maret University, Surakarta \\ 4) Masters Program in Educational Technology, \\ Sebelas Maret University, Surakarta
}

\begin{abstract}
BACKGROUND: Child development is an important parameter of child health. Child development is influenced by several factors including prenatal condition, culture, family socioeconomic status, nutrition, climate or weather, exercise, child position in the family, intelligence, and hormonal influence. Somatotrophic hormone and thyroid hormone stimulate body metabolism. Parental factors such as parental emotion, education, and experience, may also affect child development. This study aimed to estimate the association between maternal education, family income, and infant development.
\end{abstract}

SUBJECT AND METHODS: This study was a cross sectional study conducted in Surabaya, East Java. A sample of 215 children aged 24 to 36 months from Setro hamlet, Tambaksari sub-district, Surabaya, East Java. The independent variables were family income and maternal education. These variables were measured by a questionnaire. The dependent variable was child development. This variable was measured by Pre Screening of Development Questionnaire (Kuesioner Pre Skrining Perkembangan, KPSP), which was developed by the Ministry of Health. The data was analyzed by a multiple linear regression.

RESULTS: There were positive relationships between family income $(\mathrm{b}=1.14 ; 95 \% \mathrm{CI}=0.37$ to $1.92, \mathrm{p}=0.005)$, maternal education $(\mathrm{b}=1.58$; $95 \% \mathrm{CI}=0.58$ to $2.58 ; \mathrm{p}=0.002$ ) and child development. Children aged 2 to 3 years old with family income $>$ Rp 2.000.00o per month had better child development than those with lower income. Children aged 2 to 3 years old with high school or higher maternal education had better child development than those with lower education.

CONCLUSION: Higher maternal education and higher family income have positive impact on child development.

Keywords: maternal education, family income, child development 